\title{
Health Tourism: Customer Satisfaction with Reference to Amala Ayurvedic Hospital and Research Centre, Thrissur, Kerala
}

\author{
E. Beny Paul \\ Assistant Professor, Vimala College, Kerala, India \\ E-Mail: binipaul9jun@gmail.com
}

\begin{abstract}
The growth in the health tourism sector has been inspiring in India and the world. It is acknowledged fact that India has incredible prospective for progress of tourism. The assortment of India's natural abundance provides the basis of a eclectic range of tourist yields and experience which embrace business, leisure, culture, adventure, spirituality, eco- tourism, sport tourism, religious tourism and many other chases. Among the unalike tourism products, Health tourism is a relatively new type of tourist activity where the main focus of travel is improving one's health, physical appearance or fitness. So in this paper an effort has been made to study the satisfaction level of customers to Ayurveda which is one of the key elements of health tourism.
\end{abstract}

Keywords: Health tourism, Customer satisfaction, Ayurveda

\section{INTRODUCTION}

Health Tourism has now become a fastest growing sector in the country. Health tourism is actually a blend of medical tourism and wellness tourism. Medical tourism refers to the people travelling across the nation other than their own country for medical treatment whereas wellness tourism is travel for the purpose of promoting health and wellbeing through physical, psychological, or spiritual activities i.e. rejunivation. So health tourism is a broader concept. Even though all these terms are used interchangeably as all are dependent.

Customer satisfaction is a term frequently used in marketing. It is a measure of how products and services supplied by a company meet or surpass customer expectation. It is an abstract concept and involves such factors as the quality of the service provided, the atmosphere of the location where the product or service is purchased and the price of the product or service. So it is necessary that high level of customer gratification is necessary for bringing up health tourism. As a contented customer, it can bring over laurels to the industry. As far as health tourism is concerned it mainly consists of foreign nationals, the satisfaction of the industry will spread globally.

As far as health tourism in Kerala, it mainly consists of Ayurveda.For the last three decades, an ever increasing number of foreigners have visited India for Ayurveda treatment. Located at the south-western tip of the country, and bordered by the Arabian Sea to the west and the state of Tamil Nadu to the east, Kerala is the main destination in India for 'Ayurveda health tourism.'
There have many studies conducted over years about health tourism both at national and international levels. Few of them have been mentioned below:

Lončarić et al., (2015) conducted a study on "Health tourism, customer satisfaction and quality of life: The role of specialty hospitals" was to clarify the role of specialty hospitals in improving patient's health and their quality of life. The study as focused on establishing how patients perceive the influence of the services of specialty hospital for medical re- habilitation on their physical quality of life and life satisfaction. The study was based on the survey of sample of patients who used health care services of a specialty hospital. Also the hypothesis tested by implementing partial least square structural equation modeling. The study shows staying in specialty hospital is a tool to improve physical quality of life of patients. The researchers confirmed that the patient's satisfaction has a positive impact on their loyalty to the hospital.

Varzi et al., (2015) conducted a study on "The health tourist's satisfaction level of service provided" was administered to evaluate the health tourist's satisfaction of provided services in Lorestan University of Medical Sciences affiliated hospitals in 2015. Researchers investigate patient satisfaction level in various medical, nursing and hostelling aspects. Patients were selected by random sampling from among the patients of Lorestan University of Medical Sciences affiliated hospitals in 2015 spring. The data collected through semi structured questionnaire has 62 general and specific items scaled on four points. The result of the study found that, while treating patients, patient centered issue and patient's need and preferences should be focused on to enhance healthcare quality. Also, the study reveals the need of organizational management approach toward the customer preferences management and needs.

Kim et al., (2015) on "Satisfaction and subjective wellbeing of health tourists: The case of Japanese and Korean Tourists" was conducted to examine the differences of perception between health tour seekers and non-seekers of subjective well- being (SWE). Relative data were collected from 158 Korean package tourists who traveled to Sapporo, Japan and 111 Japanese package tourists who traveled to Bussan and Korea. The result indicated that health tourism seekers perceived the level of contribution of the health tour 
to SWE to be more positive than non-seekers. It also revealed the satisfaction levels of the tourism activities had a partially significant impact on the SWE of participants and non-participants.

\section{STATEMENT OF THE PROBLEM}

India is one of the Health tourism destinations with cheapest cost of medical treatment. The reason behind the growth of Health tourism market is nothing but customer satisfaction. The health tourists to Kerala have a lot many options to choose from a long list of hospitals and resorts of Kerala. These hospitals and resorts are much ahead of their time in terms of medical services provided to the patients. The hospitals of Kerala are well equipped of accommodating and treating a multitude of medical tourists at the same time. The state of the art infrastructure and health facilities provided to patients are excellent. The services or facilities offered by hospitals are different. The change in quality of services will affect the health tourism market. Thus the study on customer satisfaction in health tourism is conducted to explore the changing customer requirements and to determine the health tourist arrival for the time period with special reference to hospital concerned.

\section{OBJECTIVES OF THE STUDY}

1. To find out the factor for selecting the "AmalaAyurvedic Hospital\& Research Centre, Thrissur”

2. To analyse the level of satisfaction of foreign patients towards the facilities offered by the Hospital.

\section{A. Research Methodology}

The data was collected from both primary and secondary source. The primary data was collected through questionnaire from the patients of "AmalaAyurvedic Hospital\& Research Centre, Thrissur”. Only foreign patients are included in the study. The entire population of 40 was taken for the study as at the time of study there were only 40 patients. The period of study was from February 2017 to June 2017. Secondary data are collected from journals, books, magazines, and internet etc. Tools used for analysis were percentage analysis, one sample t -test and weighted average analysis.

\section{B. Limitations}

1. Only one hospital is taken for the study.

2. Due to the time and cost constraints, the study is time bound.

Table I shows that among the total respondents majority are German that is $22 \%$ followed by Swedish that is $17 \%$, Canadians15\%, and Srilankan10\%.Respodents of Italian, Norwegians and Czech Republican constitutes 8\%. Malaysian nationality constitutes $7 \%$. And among the total respondents British is the minority with $5 \%$.
TABLE I CLASSIFICATION OF RESPONDENTS ON THE BASIS OF NATIONALITY

\begin{tabular}{|l|c|c|}
\hline \multicolumn{1}{|c|}{ Nationality } & Frequency & Percent \\
\hline British & 2 & 5 \\
\hline Czech Republican & 3 & 8 \\
\hline Sri Lankan & 4 & 10 \\
\hline Norwegian & 3 & 8 \\
\hline Italian & 3 & 8 \\
\hline Malaysian & 3 & 7 \\
\hline Canadian & 2 & 5 \\
\hline British & 3 & 8 \\
\hline Czech Republican & 4 & 10 \\
\hline Sri Lankan & 3 & 8 \\
\hline \multicolumn{2}{|c|}{ Source: Primary Data }
\end{tabular}

TABLE II TREATMENTS TAKEN By THE RESPONDENT

\begin{tabular}{|l|c|c|}
\hline $\begin{array}{c}\text { Treatment taken } \\
\text { by the respondent }\end{array}$ & Frequency & Percent \\
\hline Disease & 28 & 70.0 \\
\hline Rejuvenate & 12 & 30.0 \\
\hline Total & 40 & 100 \\
\hline \multicolumn{2}{|c|}{ Source: Primary data } \\
\hline
\end{tabular}

Table II shows that, $70 \%$ of the respondents are taking treatment for disease which constitutes the majority. And $30 \%$ of the respondents are taking treatment for rejuvenation.

TABLE III FACTORS FOR SELECTING THE CONCERNED HOSPITAL

\begin{tabular}{|l|c|c|}
\hline \multicolumn{1}{|c|}{ Factors } & Weighted Average & Rank \\
\hline Quality of treatment & 9.38 & 1 \\
\hline Facilities & 7.14 & 2 \\
\hline Price & 6.57 & 3 \\
\hline Authentic medicine & 5.71 & 4 \\
\hline Personal services & 5.52 & 5 \\
\hline Location & 5.19 & 6 \\
\hline others & 4.87 & 7 \\
\hline \multicolumn{2}{|c|}{ Source: Computed data } \\
\end{tabular}

Table III shows that "Quality of treatment "has secured first rank (9.38), followed by "Facilities" with the second highest weighted average (7.14) and "Price" has secured third rank with the weighted average (6.57). Further, the factor "Authentic medicine" secured the fourth rank (5.71) and "Personal services" has secured the fifth rank (5.52). "Location" has secured the sixth rank with the weighted average score 5.19. Finally, other factors have been ranked seventh (4.87)

$H_{0}$ : The respondents' opinion towards facilities is equal to average 
TABLE IV RESPONDENTS ‘OPINION TOWARDS FACILITIES

\begin{tabular}{|l|c|c|c|c|}
\hline \multicolumn{1}{|c|}{ Sub scales } & Mean & Std. Deviation & t value & p value \\
\hline $\begin{array}{l}\text { Full time services of qualified \& experienced } \\
\text { Ayurveda consultant or Therapist }\end{array}$ & 4.58 & 0.500 & 19.000 & $<0.001^{* *}$ \\
\hline Well-equipped treatment facilities & 4.50 & 0.507 & 17.748 & $<0.001^{* *}$ \\
\hline Certified Ayurveda pharmacy & 4.50 & 0.507 & 17.748 & $<0.001^{* *}$ \\
\hline Homely attentive service & 4.64 & 0.487 & 20.186 & $<0.001^{* *}$ \\
\hline Herbal\& natural accessories & 4.53 & 0.506 & 18.105 & $<0.001^{* *}$ \\
\hline Special Therapeutic diet & 4.11 & 0.919 & 7.255 & $<0.001^{* *}$ \\
\hline Yoga\& meditation center & 4.31 & 0.577 & 13.584 & $<0.001^{* *}$ \\
\hline Communication facilities & 4.17 & 0.775 & 9.037 & $<0.001^{* *}$ \\
\hline Accommodation facilities & 4.39 & 0.494 & 16.855 & $<0.001^{* *}$ \\
\hline \multicolumn{2}{|c|}{ Source: Computed data } & *ndicate significance at $1 \%$ level (test value 3$)$ &
\end{tabular}

Table IV presents the respondents opinion on facilities. It is clear from the table that the mean values is greater in the subscale of homely and attentive service with mean value 4.64 and it is followed by subscale full time services of qualified\& experienced Ayurveda consultant or Therapist, Herbal \&natural accessories, Well-equipped treatment facilities, Certified Ayurveda pharmacy, Accommodation facilities, Yoga\& meditation center, Communication facilities and Special Therapeutic diet with mean values $4.58,4.53,4.50,4.50,4.30,4.31,4.17$ and 4.11 respectively. Since the p value of this factor is less than 0.001 , the null hypothesis is rejected at $1 \%$ level of significance. Hence it can be concluded that the respondents' opinion in this factor is not equal to average. Based on the mean scores it is evident that the opinions are above average level.

TABle V Classifications Of ResPondents On The Basis OF NUMBER OF VISITS

\begin{tabular}{|l|c|c|}
\hline \multicolumn{1}{|c|}{ Number of visits } & Frequency & Percent \\
\hline First visit & 7 & 17.5 \\
\hline Second visit & 8 & 20.0 \\
\hline Repeat visit & 15 & 37.5 \\
\hline Multiple visit & 10 & 25.0 \\
\hline Total & 40 & 100.0 \\
\hline \multicolumn{2}{|c|}{ Source: Primary data } \\
\hline
\end{tabular}

It is evident from the table $\mathrm{V}$ that majority of the respondents visit repeatedly which constitutes $37.5 \%$ and it is followed by multiple visit that is $25 \%$. About $20 \%$ of the respondents made second visit and $17.5 \%$ of the respondents visited for the first time.

\section{FINDINGS}

1. Among the total respondents majority are Germans that is $23 \%$ whereas British constitute the least i.e. $5 \%$

2. $70 \%$ of the respondents are taking treatment for disease which constitutes the majority. And $30 \%$ of the respondents are taking treatment for rejuvenation.

3. Majority of the respondents are have selected the particular hospital for the quality service offered by them followed by the facilities, prices, authentic medicines, personal services, location and other factors provided by the hospital.

4. It is found that the mean values is greater in the subscale of homely and attentive service with mean value 4.64 and mean values are low in the case of Communication facilities and special Therapeutic diet that is 4.17 and 4.11 respectively. Since the p value of this factor is less than 0.001, the null hypothesis is rejected at $1 \%$ level of significance. Hence it can be concluded that the respondents' opinion in this factor is not equal to average. Based on the mean scores it is evident that the opinions are above average level.

5. Majority of the respondents visit repeatedly which constitutes $37.5 \%$ and also $25 \%$ of the customers have made multiple visits.

\section{CONCLUSION}

Customer satisfaction is very important for the survival of any entity. The study shows that the customers are happy with the services and facilities provided by "Amala Ayurvedic Hospital and Research Centre". This is evident from the fact that the mean value of the facilities provided by the hospital is above average which means the customers are satisfied with the facilities provided by the hospital. And also the repeated and multiple visits by the customers to the hospitals demonstrate that the customers are gratified with the hospital. The conclusion in the present study is therefore, that people act in a rational way due to the fact that they become satisfied.So the conclusion of the study Health Tourism: Customer Satisfaction With Reference To Amala Ayurvedic Hospital \& Research Centre, Thrissur” is that customers are satisfied with the Hospital and its services.

\section{REFERENCES}

[1] Bindhu, V. T. (2012). Customer preference and satisfaction in health tourism: a study of selected Ayurvedic resorts in Kerala.

[2] Boga, T. C., \&Weiermair, K. (2011). Branding new services in health tourism. Tourism Review, 66(1/2), 90-106.

[3] Dinu, M., Zbuchea, A., \&Cioacă, A. (2011). Health Care Tourism in Romania: Main Features and Trends. 
[4] Fuchs, G., \&Reichel, A. (2010). Health tourists visiting a highly volatile destination. Anatolia, 21(2), 205-225.

[5] Hassan, M. M., \&Shahnewaz, M. (2014). Measuring tourist service satisfaction at destination: A case study of Cox's Bazar sea beach, Bangladesh. American Journal of Tourism Management, 3(1), 32-43.

[6] Health tourism: definition focused on the Swiss market and conceptualization of health (i) ness. Journal of health organization and management, 26(1), 60-80.

[7] Kim, H. J., Lee, T. J., \&Ko, T. G. (2016). Satisfaction and subjective well-being of health tourists: The case of Japanese and Korean tourists. Journal of Travel \& Tourism Marketing, 33(5), 742-756.

[8] Lončarić, D., Lončarić, D., \&Markovic, S. (2015). Health Tourism, Customer Satisfaction and Quality of Life: The Role of Specialty Hospitals.
[9] Lunt, N., \& Carrera, P. (2010). Medical tourism: assessing the evidence on treatment abroad. Maturitas,66(1), 27-32.

[10] Marković, S., Lončarić, D., \&Lončarić, D. (2014). Service quality and customer satisfaction in the health care industry-towards health tourism market. Tourism and hospitality management, 20(2), 155170.

[11] Varzi, A. M., Saki, K., Momeni, K., Vasokolaei, G. R., Khodakaramifard, Z., Zouzani, M. A., \&Jalilian, H. (2016). The Health Tourists' Satisfaction Level of Services Provided: A CrossSectional Study in Iran. Global journal of health science, 8(9), 294. 